tion." We promise that the intellectual stimulus of the Conference will match the excitement of Baltimore, known to its enthusiasts as "Charm City." In
1986 be charmed by all that Baltimore has to offer the mind and the senses.

\title{
A closer eye on appraisals: A clarification
}

\author{
By John R. Payne \\ Assistant to the Director \\ Harry Ransom Humanities Research Center \\ University of Texas at Austin
}

Public response to "A closer eye on appraisals" in the February issue of $C \& R L$ News, pp.52-56, indicates an uneasiness about that portion of the Tax Reform Act of 1984 relating to donee record keeping requirements. Essentially this provision relates only to gifts that are valued over $\$ 5,000$. The actual wording of the law reads: "if the claimed value of such property (plus the claimed value of all similar items of property donated by the donor to one or more donees) exceeds $\$ 5,000$."

The new federal regulations must be interpreted through reference to two separate U.S. Government publications: 1) The law as described in Conference Report on the Deficit Reduction Act of $1984^{\mathrm{I}}$ which contains all the provisions of the Tax
Reform Act of 1984; and 2) the temporary Rules and Regulations as published in the December 31, 1984, issue of the Federal Register. ${ }^{2}$

The Rules and Regulations describe how the new law will be carried out. They are considered "temporary" in order to allow for public review and comment. Persons who wish to comment on the Rules and Regulations are encouraged to con-

1"“The Tax Reform Act of 1984," Conference Report on the Deficit Reduction Act of 1984: Federal Taxes, Prentice-Hall Bulletin 29 Extra, June 29, 1984.

${ }^{2}$ Federal Register, Vol. 49, No. 252 (December $31,1984)$.

\section{Midwest Library Service}

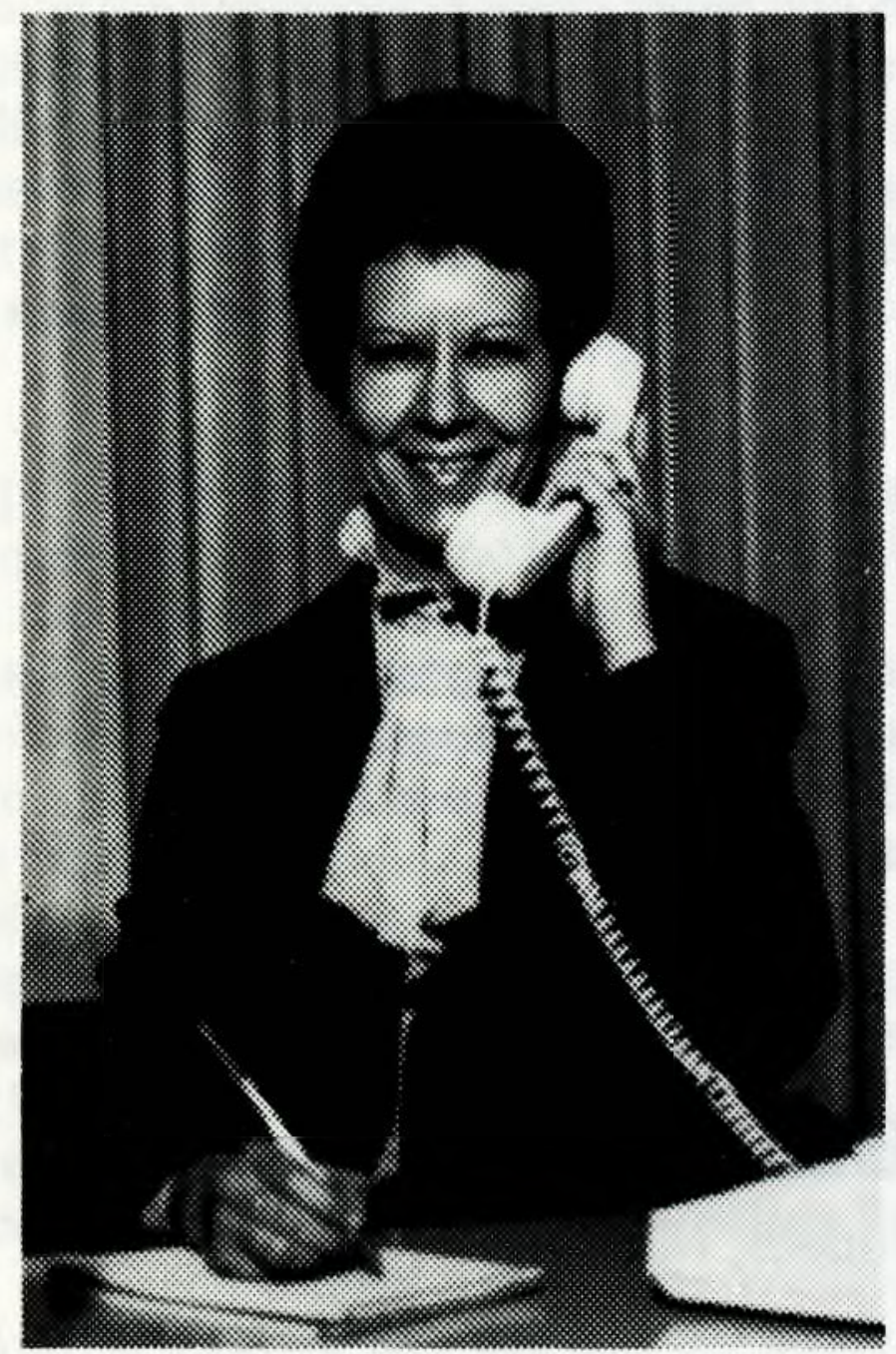

\section{You won't find more personal attention ... anywhere}

College and university librarians: We have what you're looking for. While Midwest utilizes state-of-the-art computer systems, we realize machines can't do it all. So when you want to place an order, ask a question, or discuss a problem, you can call direct on Midwest's toll-free WATS line and conduct business on a nameto-name basis with your personal customer service representative. It's the kind of attention that Midwest has provided to college and university libraries for 24 years.

Call toll-free (800) 325-8833

Missouri librarians call toll-free (800) 392-5024 Canadian librarians call collect (314) 739-3100 
tact Beverly Baughman, the IRS attorney who drafted them. Her address is: Legislation and Regulations Division, Office of the Chief Counsel, Internal Revenue Service, 1111 Constitution Avenue, N.W., Washington, DC 20224, Attention: CC.LR.T; (202) 566-3297 (not a toll-free call.)

According to Baughman, hearings on the Rules and Regulations are scheduled in Washington in late March or April. Permanent Rules and Regulations incorporating the required changes will be published by mid-year.

Two sections of the new law require the use of new IRS forms. Item 2 relating to the appraisal summary must be prepared on the "Appraisal Summary" form, No. 8283. Item 5 relating to donee record keeping must be prepared on the "Donee Information Return" form, No. 8282. These two forms should be available in IRS distribution centers by mid-March and somewhat later in IRS district offices.

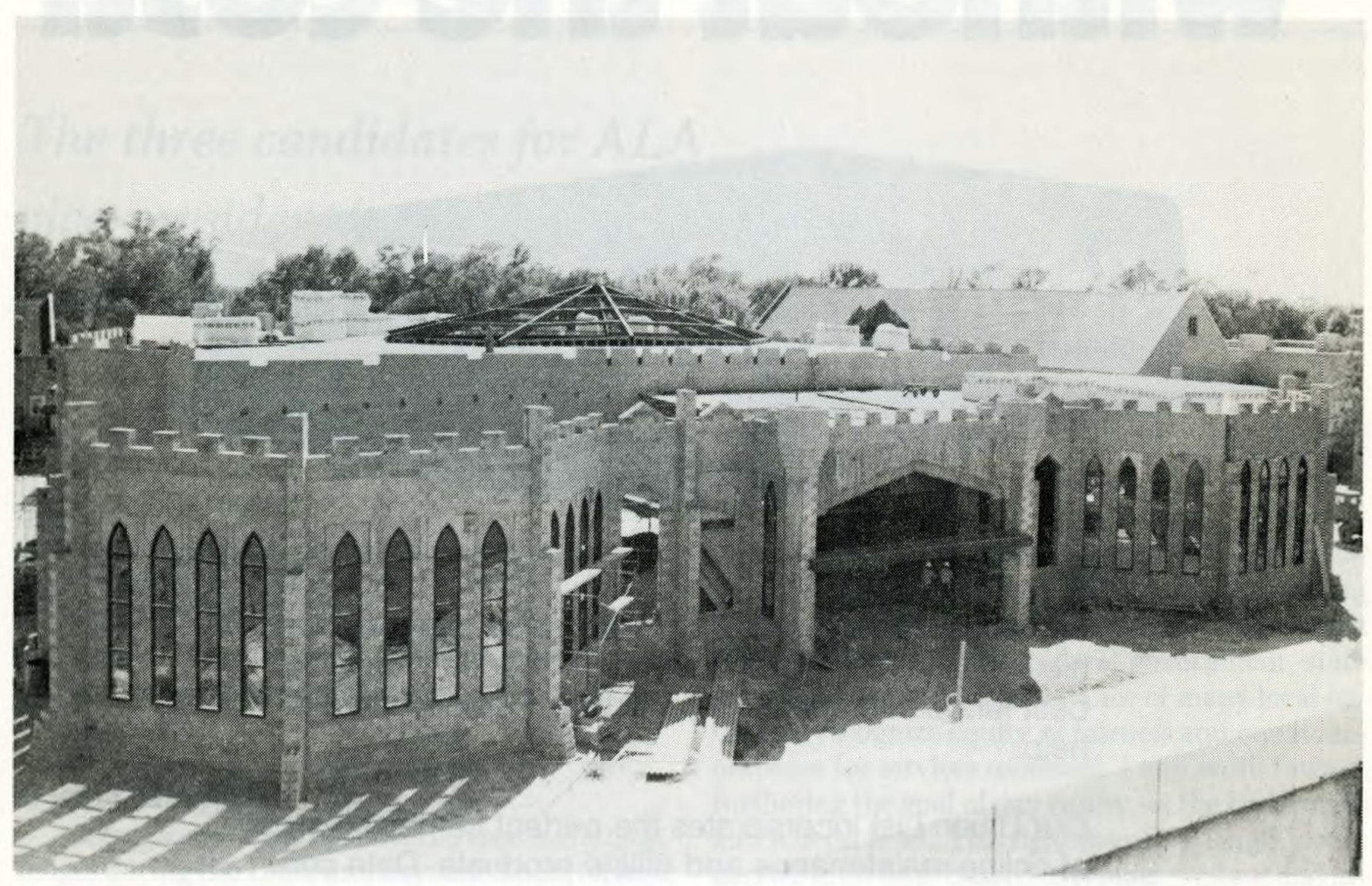

New library under construction at the New Mexico Military Institute, Roswell.

\section{New Mexico Military Institute to have new automated library}

The Paul Horgan Library at the New Mexico Military Institute, Roswell, will be fully automated when it moves to its new location, the J. Penrod Toles Learning Center, in August. The library chose CLSI's LIBS 100 System 73 for circulation control, public catalog, reserve, media booking, and interlibrary loan.

The new automated Learning Center, which will serve as a research resource for the community of Roswell as well as the students at the Institute, will be expanded further to include other libraries and academic institutions in southeastern New Mexico. Besides the Horgan Library, the 38,000 square foot building will also feature a Large Group Lecture Hall for meetings and lectures; a Television Production Studio for on-campus and community cable applications; a Student Assistance Center with an academic counseling service; learning labs; and ample study space for the school's 950 students. A dedication ceremony will be held at Homecoming in late October.

The crenellated, military gothic motif of the new facility matches the architectural style of the other buildings on campus. The library and bookstacks are arranged in a radial pattern with the reference area in the center. Other architectural highlights include custom-made Cordovan oak furniture, and an insulated, translucent, fiberglass skylight with a grid pattern that accentuates the raised ceililng. The architects are Wagner and Associates of Roswell.

Founded in 1891, New Mexico Military Institute is a four-year high school and two-year junior college. It is the largest military junior college of its type in the nation and stands second to West Point in commissioning officers for the U.S. Army. 


\section{Currency without the cost.}

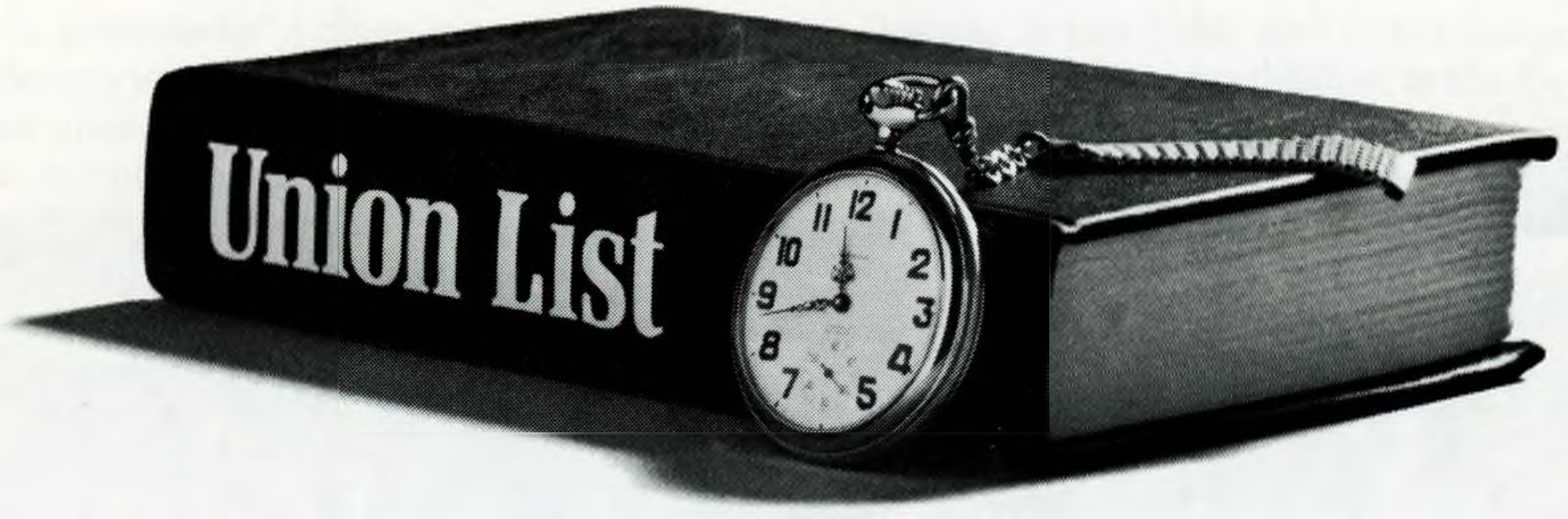

Theser

he cost of keeping a Union List current can be prohibitive. The staff hours alone are enough to make the best funded libraries cringe. Unless Faxon is there to help.

Our Union List incorporates the perfect combination of online maintenance and offline products. Data conversion takes 1-4 months. You can add holdings without full cataloging of records. And Union List is fully compatible with your local system.

Now you can generate the up-to-date information you want as hard copy, tape, or microfiche. More frequently and accurately than previously possible. And at reduced cost.

Let the savings begin. The call's on us.

$800225-6055$ or $617329-3350$ collect

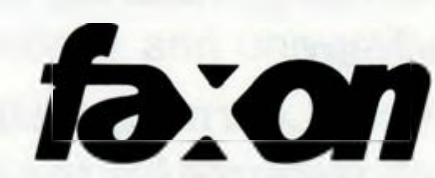

ON THE FRONTIER OF INFORMATION MANAGEMENT

The Faxon Company, Inc. 15 Southwest Park Westwood, MA 02090 